\title{
Ušlechtilé nápoje
}

\section{Káva, čaj a čokoláda na šlechtických sídlech Čech a Moravy ve dru- hé polovině 17. a v 18. století na základě výzkumu zámeckých} a palácových inventářů

\author{
DANA MAREŠOVÁ
}

„Pane profesore, povězte nám, kolik šálků káry rypila šlechtična X? Načež pan profesor dobromyslnè odpovidal: To vám nepovím, ale povím vám, kolik párů punčoch mèla do výbavy..." Zdenka Villaniová (1846-1880) si takto dobírala profesora Karla Vladislava Zapa (1812-1871), jenž trávil svioj čas na zámku Střižkov nedaleko Benešova. Zámek zakoupil Karel Drahotín Villani (1818-1883), který na něj společně s manželkou Matyldou (1826-1885) zval měšt’anskou (převážně pražskou) společnost na prázdniny. ${ }^{2}$ Výše uvedený citát ukazuje na to, že měštanská společnost druhé poloviny 19. století přemýšlela o exotických pochutinách, ale ještě nedokázala odpovědět na všechny otázky spojené s dějinami každodennosti šlechticů. Úryvek pochází z doby, kdy popíjení kávy (ale i čaje a čokolády) představovalo běžnou záležitost v městském i venkovském prostředí.

Ovšem jejich konzumace vždy závisela na finančních možnostech kupujících. ${ }^{3}$ Zprvu ale tyto pochutiny využívaly pouze privilegované vrstvy společnosti.

Počátky zájmu o získávání exotických produktů, pochutin a předmětů lze nalézt již v dobách prvních zámořských cest a následných objevio. Novinky ze vzdálených světů budily v raně novověké společnosti na jedné straně fascinaci, na druhé strach. Mnohé ze zprvu odmítaných novot se později rozširíily natolik, že je dnešní svět každodenně užívá. Česká historiografie se však prozatím exotickým nápojům plně nevěnovala. ${ }^{4}$ Proto se předkládaný článek zaměří na stolní kulturu urozenců, představí místnosti šlechtických sídel, ve kterých se exotické nápoje prripravovaly a popíjely, proces jejich servírování, druhovou a materiální skladbu, a pokusí se zachytit s tím související témata jako otázky reprezentace, uměleckého cítění či myšlení šlechticů.

1 Maryša Radoňová-Š́́recká, Salony. S doborými podobiznami, Praha 1920, s. 81.

2 David Procházка, Emanuel Engel - dètství a zrání pražského vlastence (1844-1870), Sborník vlastivědných prací z Podblanicka 49, 2009, s. 53-95, zde s. 86.

3 Milena Lenderová, Peněžni deníky ,druhého pohlavi“"ve druhé polovinè ,,dlouhébo" 19. století, Theatrum historiae 6, 2010, s. 321-332, zde s. 326.

4 Kávou, čajem a čokoládou a pohledům na ně z dietetického hlediska se zabýval Karel ČErnÝ, Káva, čokoláda, čaj a jiné požitky kuchyně i lékárny 17. století, in: Zdeňka Buršíková - Václav Chroust - Karel Viták (edd.), Dělám to k větší slávě boží a chvále vlasti. Bohuslav Balbín a jeho doba, Klatovy 2014, s. $138-168$. 
Z Ameriky, Asie a Orientu si šlechtici postupně začali na svá sídla pořizovat exotické květiny, koření, ovoce a zeleninu, zviŕata, koberce, zbraně a další exotika. Mezi ně patřila i káva, čaj a čokoláda jako ingredience $\mathrm{k}$ př́ípravě nápojů. Zprvu se raně novověká společnost $\mathrm{k}$ chuti a vůni těchto pochutin stavěla ostražitě. I přesto lze nalézt kořeny používání exotických produktů u české a moravské šlechty již ve druhé polovině 17. století. ${ }^{5}$ Postupně se počáteční nedůvěra u šlechty zmenšovala, a tak káva, čaj a čokoláda začaly být vyhledávány pro své povzbuzující účinky a nakonec i jako lék na rozličné neduhy. ${ }^{6} \mathrm{~S}$ kávou se poprvé seznámil Kryštof Harant z Polžic a Bezdružic (1564-1621) v roce 1598 při cestě do Cařihradu. ${ }^{7}$ Uběhlo více než sto let a v Čechách a na Moravě byly zakládány první kavárny. ${ }^{8}$ Urozenci se ve svých zámeckých a palácových zahradách snažili pěstovat kávovníky. V 18. století lze tyto snahy doložit u Questenberků na zámku v Jaroměřicích a na sokolovském zámku Nosticů. ${ }^{9}$ Stejně tak byla značně zdlouhavá cesta čaje z Asie a čokolády z Ameriky na stoly české a moravské šlechty. ${ }^{10} \mathrm{~V}$ 18. století káva, čaj a čokoláda už představovaly běžnou součást šlechtických domácností. Pro šlechtice se exotické pochutiny a nápoje staly symbolem luxusu, společenského postavení a reprezentačního úsilí.

Zodpovědět otázky týkající se hmotné kultury exotických nápojů a z ní vyplývajícího každodenního života na šlechtických sídlech pomohly zámecké a palácové

5 Dana MArešovÁ, Káva, čaj a čokoláda v každodenni kultuře raně novověkých šlechtických sídel v českých zemích, České Budějovice 2015 (Diplomová práce). Poděkování za volbu tématu, rady a vedení práce patří prof. PhDr. Václavu Bůžkovi, CSc. Základem zmíněné práce se staly inventáře zámeckých sídel a městských paláců v rozmezí od poloviny 17. do konce 18. století. Káva, čaj a čokoláda se na základě výzkumu v uvedené diplomové práci pila u Althanů, Berchtoldů, Buquoyů, Collaltů, Černínů, Ditrichštejnů, Eggenberků, Forgatschů, Harrachů, Magnisů, Nosticů, Petřvaldských, Questenberků, Rottalů, Schwarzenberků, Valdštejnů, Windischgrätzů a Žerotínů.

6 K. Č́ ERnÝ, Káva, s. 153-154.

7 Alena Křížová, Káva, čaj a čokoláda ve šlechtickém salonu, Brno 2006 (= Katalog k výstavě konané na Státním zámku Vranov nad Dyjí), s. 6.

8 Lydia Petráňová, Die Anfänge des Kaffeetrinkens in Böhmen und die Rolle der Kaffeegesellschaften in der tschechischen nationalen Wiedergeburt, in: Daniela U. Ball (ed.), Kaffee im Spiegel europäischer Trinksitten, Zürich 1991, s. 203-206, zde s. 203.

9 Moravský zemský archiv (dále MZA) Brno, G 436 Rodinný archiv (dále RA) Kouniců - jeho součástí je RA Questenberků, inv. č. 6126, kart. 737 (inventář zámku Jaroměřic nad Rokytnou 1752). Za poskytnutí přepisu inventáře děkuji PhDr. Rostislavu Smíškovi, Ph.D. Zahradou v Jaroměřicích se zabývala Lenka Křesadlová, jedna z jejich prací nese název Exotická krása a autorka v ní reflektuje pěstování exotických rostlin (citrusů, ananasů, ale i kávovníků a dalších). Srov. Petr FIDLER - Lenka KŘesadlová - Jana Perut ková - Lilian Ruhe - Jana Spáčilová - Tomáš Valeš, Promèny zámeckého areálu v Jaroméricich nad Rokytnou, České Budějovice 2017, s. 229-272.

10 Annerose Menninger, Genuss im kulturellen Wandel: Tabak, Kaffee, Tee und Schokolade in Europa, 16-19. Jabrhundert, Stuttgart 2004, s. 356. 
inventáře. ${ }^{11}$ Tyto písemné prameny se hojně dochovaly $\mathrm{v}$ archivech a dnes slouží jako průvodci po interiérech sídla a ukazují jeho podobu. ${ }^{12} \mathrm{Z}$ více jak osmdesáti prozkoumaných inventářů vyplývá, že se káva, čaj i čokoláda těšily u šlechty v Království českém i Markrabství moravském velké oblibě. Ve zkoumaném 18. století představovala šlechtická sídla symbolický prostor. Odrážela se v nich nejen moc a urozenost majitele, ale také jeho kulturní smýšlení a reprezentační snahy. ${ }^{13}$ Inventáře sídel tak badatelům $\mathrm{v}$ podstatě umožňují číst v myslích jejich majitelů.

Urozenci mnohdy vlastnili několik sídel a do každého z nich vkládali určité množství svých snah. ${ }^{14}$ Např́klad $v$ případě Nosticů došlo k porovnání inventáře městského paláce $\mathrm{v}$ Praze $\mathrm{z}$ roku 1736, kdy v něm pobýval hrabě Antonín Jan (1652-1736), s inventáři hraběte
Františka Václava (1697-1765) z roku 1765 , a to s jeho rezidencí v Praze, Řehlovicích a Sokolově. V pražském paláci Antonín Jan Nostic vystavoval značné množství zkoumaných předmětů, oproti tomu venkovská rezidence Františka Jana v Řehlovicích neobsahovala žádné př̀edměty ke konzumaci exotických pochutin. Bylo to způsobeno tím, že toto sídlo se využívalo pouze jako vedlejší venkovská rezidence. Palác v Praze v roce 1765 neskýtal téměř žádné př̀dměty, které sloužily k reprezentaci majitele. Bylo to nejspíše zapříčiněno tím, že tu František Václav netrávil tolik času, jelikož pobýval více na sokolovském zámku. $Z$ toho vyplývá, že si oba dva členové nostického rodu oblíbili exotické předměty, kterými se obklopovali v sídlech, v nichž právě pobývali. ${ }^{15}$ Šlechtici prostřednictvím předmětů demonstrovali svůj životní

11 Šlechtickými inventáři se zabýval např. Václav BůžEx, Adelige und bürgerliche Nachlaßinventare des 16. und 17. Jahrhunderts in den böhmischen Ländern, in: Josef Pauser - Martin Scheutz - Thomas Winkelbauer (edd.), Quellenkunde der Habsburgermonarchie (16.-18.Jahrhundert). Ein exemplarisches Handbuch, Wien 2004, s. 468-476; Martin Pleva, Hmotná kultura morarské barokni šlechty ve svétle pozionstalostních inventárú, Časopis Matice moravské 85, 2000, s. 131-155; Richard Š́peK, Pozisstalostní inventár Otty mladšího z Nostic, Opera romanica 4, 2003, s. 361-376. Obecně k hmotné kultuře raného novověku Josef Petráň, Dějiny hmotné kultury II/1-2. Kultura každodenního života od 16. do 18. století, Praha 1997.

12 Eva Lukášová - Vendula OTAvs Ká, Aristokratický interiér doby baroka ve svètle historických inventárüu, Praha 2017, s. 13-20; Michaela Neudertová, ,,Item ve velkém fraucimře před lusthausem se nachází... "(Př́spévek ke studiu inventárư pozdnè renesančních rezidencí v severozápadních Čechách), Opera historica 7, 1999, s. 163-199.

13 Friedrich Polleross - Andrea Sommer-Mathis - Christopher F. Laferl (edd.), Federschmuck und Kaiserkrone. Das barocke Amerikabild in den habsburgischen Ländern, Wien 1992; F. Polleross, Adelige Repräsentation in Architektur und bildender Kunst vom 16. bis 18. Jahrbunderts in Ostösterreich. Literatur und Forschungsüberblick, Opera historica 2, 1992, s. 49-59.

14 O rezidenční síti zkoumaného období Jiří Kubeš, Reprezentační funkce sídel vyšši šlechty z českých zemi (1500-1740), České Budějovice 2005 (Disertační práce).

15 Státní oblastní archiv (dále SOA) Plzeň, pracoviště Klášter u Nepomuku, RA Nosticů, inv. č. 1114, kart. 160 (inventář pražského paláce 1736, nefoliované strany); тAмTÉž, inv. č. 170, kniha 71 
styl, proto si vybírali, v jakých typech sídel předměty vystavovat. Obecně byly $\mathrm{v}$ tomto ohledu bohatší paláce a vzápětí za nimi následovala hlavní venkovská sídla. Vliv na výskyt předmětů mělo i to, jestli urozenec pobýval na svém sídle celý rok, nebo se tu vyskytoval jen př́ležitostně. Hodnotnější předměty se objevovaly $\mathrm{v}$ sídlech, kde šlechtic přebýval nejčastěji, tam mu mohly sloužit k vytoužené reprezentaci.

Těmto novým pochutinám začali šlechtici prizpůsobovat nejen místnosti na svých sídlech, ale také nádobí, které vzniklo speciálně pro pití nápojů. ${ }^{16}$ Předměty sloužící $\mathrm{k}$ přípravě a konzumaci kávy, čaje a čokolády se nacházely jak $\mathrm{v}$ prostorech obslužných, tak i obytných. Nádobí na popíjení kávy, čaje a čokolády se objevovalo $v$ reprezentačních místnostech, jakými byly kabinety, pánské a dámské pokoje, stř́ibrnice a galerie. Nacházelo se i v soukromých prostorách jako ložnice. Předměty se ukládaly do kredencí, či byly součástí stolního nádobí. Mohly být skryté v komorách, skladech, skřríních a truhlách. $Z$ obslužné části zámku či městského paláce pak byly př́tomny zejména $\mathrm{v}$ kuchyni a cukrárně, kde tyto předměty sloužily $\mathrm{k}$ prrípravě nápojů. Šlechtici se setkávali a konverzovali nad šálkem kávy, čaje či čokolády v kabinetech, při čemž se bavili hraním rozličných her či vykonávali jinou společenskou aktivitu. V hlavní venkovské rezidenci Nové Hrady si Buquoyové ve zkoumané době vychutnávali vůně a chutě exotických nápojů v porcelánovém kabinetu. Modré a bílé kávové šálky s podšálky z drážd’anského porcelánu mohli Buquoyové nabídnout až devětadvaceti hostům. Podávali zde i čokoládu v pohárech a čaj s mlékem rozlévali z konvic do šálků. Do pokoje umístili dvě taftem potažené pohovky a čtyřri křesla stejného provedení. Buquoyové se z nich kochali oslnivou krásou vídeňského a drážd’anského porcelánu. Celou atmosféru kabinetu podtrhoval šestiramenný svícen, jenž osvětloval vystavené kusy. ${ }^{17}$ Stejné kabinety se nacházely na zámku $v$ Jaroměricích nad Rokytnou a $v$ městských palácích Nosticů a Černínů v Praze. Jejich vybavení bylo obdobné, což vyplývalo

(inventář domu v Praze 1765, nefoliované strany); TAMTÉž, inv. č. 172, kniha 73 (inventáŕ zámku Řehlovice 1765, nefoliované strany); TAMTÉž, inv. č. 173, kniha 74 (inventář zámku Sokolov 1765, nefoliované strany).

16 Ke konkrétním předmětům na šlechtických sídlech více Dana Marešová - Peter Demeter, Šlechtické neřesti. Káva a čokoláda na šlechtických sídlech Čech a Moravy, České Budějovice 2017 (= Katalog $\mathrm{k}$ výstavě konané na Státním zámku Dačice). $V$ této práci autoři pracovali především s hmotnými a ikonografickými prameny. Proto se autorka tohoto článku záměrně rozhodla použít písemné prameny (inventáře). Více k tomu, jak vypadaly zámecké interiéry ve zkoumaném období, např. Eva Lukášová, Zámecké interiéry. Pohledy do aristokratických sídel od časủ renesance do doby proní poloviny 19. století, Praha 2015, s. 103-220.

17 SOA Třeboň, RA Buquoyů, sign. 206. 339, kniha 390 (inventář hraběcí domácnosti 1767-1768, nefoliované strany). 
z jejich reprezentativní funkce - sloužily jako místo pro setkávání s hosty. ${ }^{18}$

$\mathrm{Na}$ základě výzkumu inventářů se předměty sloužící k popíjení kávy, čaje a čokolády nacházely $\mathrm{v}$ pánských a dámských pokojích. Např. v černínském pražském paláci se $\mathrm{v}$ pokoji pána vyskytovalo dvanáct pohárů na kávu a deset na čaj. ${ }^{19}$ Na zámku Police v dámském pokoji Evy Isabely Pražmové, provdané Berchtoldové $(† 1708)$, viselo na stěnách několik obrazů, jeden s motivem Panny Marie, jeden s Ježíšem Kristem ve zlatém rámu, dva s Betlémem v černém rámu a šest malých a velkých francouzských obrazů. Pro dámu nesmělo ve vybavení pokoje chybět velké zrcadlo ve zlatém rámu. $V$ místnosti stál stůl s hnědým květovaným potahem. Osm velkých modrých křesel potažených melírovaným plyšem doplňovalo šest stejných malých křesílek. K odpočinku tu sloužila dvě kanape. Celý prostor byl připraven $\mathrm{k}$ tomu, aby se dámy pohodlně usadily a konverzovaly nad šálkem kávy a čokolády. V místnosti bylo přichystáno čtyřicet šest pohárů na kávu a čokoládu vyrobených z majoliky, které si mohly dámy odkládat na čtyři servírovací stolky. ${ }^{20}$

$\mathrm{V}$ městském paláci Schwarzenberků ve Vídni se nacházela místnost, která se nazývala stříbrnice. Své místo tu měly předměty, které rod Schwarzenberků reprezentovaly. Nacházely se tu nádoby na kávu, konvice, pánve na uhlíky a kotlíky se schwarzenberským erbem. Řada předmětů sloužících k popíjení kávy, čaje a čokolády pocházela od spřízněných Eggenberků. Rodinná kontinuita a starobylost rodu Schwarzenberků se odrážela na nádobí s eggenberskými erby. ${ }^{21}$ Dále Schwarzenberkové podědili po Eggenbercích truhly s cestovním stř́brem, jehož součástí bylo i nádobí ke konzumaci kávy a čokolády. Souprava tak ukazuje na potřebu šlechtice dopřát si při své cestě šálek jedné z pochutin. ${ }^{22}$ Zastoupení ve stříbrnici mělo i porcelánové nádobí $\mathrm{k}$ popíjení čokolády a čaje. Nádoby pocházely $\mathrm{z}$,indiánské země“ a některé byly vyrobeny z ,indiánského“ dřeva. Užití výrazu

18 E. LukÁšová, Zámecké interiéry, s. 156; MZA Brno, RA Questenberků, inv. č. 6126, kart. 737 (inventáŕ zámku Jaroměřic nad Rokytnou 1752), za poskytnutí přepisu inventáře děkuji PhDr. Rostislavu Smíškovi, Ph.D.; SOA Plzeň, pracoviště Klášter u Nepomuku, RA Nosticů, inv. č. 1114, kart. 160 (inventář pražského paláce 1736, nefoliované strany); SOA Třeboň, pracoviště Jindřichův Hradec, RA Černínů, nečíslovaný fascikl k 30. dubnu 2018 (inventář pražského paláce 1733). TAмтÉž (inventář pražského paláce 1720).

20 MZA Brno, C2 Tribunál - pozůstalosti, sign. B 43, kart. 11 (inventáŕ Police 1720, nefoliované strany).

21 SOA Třeboň, pracoviště Český Krumlov, Schwarzenberská inventární kontrola České Budějovice, inv. č. 136, kniha 136 (inventář stř́íbrnice v městském paláci ve Vídni 1717, nefoliované strany); TAMTÉž, inv. č. 139, kniha 139 (inventář stř́ibrnice v městském paláci ve Vídni 1723, nefoliované strany). Srov. Václav BŮŽEK a kol., Společnost českých zemí v raném novověku. Struktury, identity, konflikty, Praha 2010, s. 293.

22 TAмте́ž, inv. č 136, kniha 136 (inventář stříbrnice v městském paláci ve Vídni 1717, nefoliované strany). Např. cestovní lahvice se dochovala na zámku v Rájci nad Svitavou, pochází z Číny z rozmezí let 1700-1740. Srov. A. KŘížovÁ, Káva, čaj a čokoláda, s. 37. 
„,indiánské“ ukazovalo na mimoevropský původ předmětů, obecně se tak označovaly předměty z Ameriky, Asie či Orientu. ${ }^{23}$ Schwarzenberská stř́ibrnice se v průběhu 18. století rozrůstala o další předměty. Jedinečným přírůstkem se stal kávový stolek, který stál na čtyřech vyřezávaných dřevěných nohách ve tvaru lva.

Schwarzenberkové v českokrumlovské galerii, v úzkém sále, který ze dvou stran osvětlovaly svícny, měli umístěné poháry na pití čokolády a porcelánový hrneček na kávu. Galerie se nevyužívaly jen $\mathrm{k}$ vystavování obrazů, ale v některých prrípadech do nich šlechtici dávali i další umělecké předměty. Prostor sloužil k reprezentaci, světla zvýrazňovala vystavená díla a měla oslnit každého $z$ přicházejících hostů. ${ }^{24}$ Proto i Černínové vybrali do své galerie pražského paláce jen ty nejhodnotnější kousky. Vystavovali tu ,indiánskou“ skřín na čaj, čínské a japonské servisy, jedinečně zdobené poháry na čokoládu apod. ${ }^{25}$ Předměty sloužící ke konzumaci exotických nápojů či $\mathrm{k}$ reprezentaci jejich majitele se nacházely i v dalších částech šlechtických sídel. V inventárích byla uvedena kaple, knihovna, ložnice, obývací pokoje a další rozličné prostory, $v$ nichž bylo umístění zkoumaných předmětů značně překvapující. Vždy se ale jednalo jen o nepatrné množství.

Káva, čaj a čokoláda se na šlechtických sídlech připravovaly v kuchyních, cukrárnách i kavárnách. ${ }^{26}$ Zámecký personál byl instruován tak, aby uvařil tyto nápoje co nejlahodnější. Ingredience $\mathrm{k}$ př́ípravě nápojů se uchovávaly v krabičkách a dózách. Po vyjmutí $\mathrm{z}$ nich byla kávová zrna zprvu rozemleta $\mathrm{v}$ mlýnku. Poté kuchař přesypal jednu z pochutin do kotlíku zahřívaného pánví s uhlíky, v němž se vařila. Někdy kuchyňský personál použil k ohřátí pouhý rendlík. $V$ případě čaje se kromě kotlíku užíval i speciální hrnec na čaj. O tom, jak vypadalo vybavení kuchyně sloužící $\mathrm{k}$ př́ípravě exotických nápojů (Kaffe Küche) v 18. století, vypovídá inventár harrachovského paláce ve Freyungu ve Vídni. ${ }^{27} \mathrm{~V}$ paláci se nacházely hned dvě takové kuchyně, a to v prvním

23 Výraz, ,indiánské“ ve spojitosti s exotickými nápoji se vyskytuje takřka ve všech zkoumaných inventáŕích. Srov. Lubomír SLAvíčer, Dvẽ podoby barokního šlechtického sbèratelství 17. století v Čechách sbirky Otty Nostice ml. (1608-1665) a Františka Antonina Berky z Dubé (1649-1706), Opera historica 5, 1996, s. 483-513, zde s. 495.

24 P. Fidler - L. KŘesadlová - J. Perut ková - L. Ruhe - J. Spáčilová - T. Valeš, Proměny, s. 215. Např. takový sál i SOA Třeboň, pracoviště Český Krumlov, Velkostatek Český Krumlov, sign. I7I8 (inventár zámku Český Krumlov 1733, nefoliované strany) a další.

25 TAMTÉž, pracoviště Jindřichův Hradec, RA Černínů, nečíslovaný fascikl k 30. dubnu 2018 (inventáŕ pražského paláce 1733).

26 Kuchyňské nádobí ze 17. a 18. století se ve srovnání s původními počty dochovalo na sídlech jen nepatrně. Často bylo zničeno, ale i prodáno, odcizeno atd. Jedna z možností, jak se lze dovědět více o vybavení kuchyní, je zkoumat jejich inventáre. Vítězslav ŠTAjNochr, Zámecké kuchyně. Zámecké kuchyně v kontextu evropskébo vývoje, Praha 2017, s. 5.

27 Österreichisches Staatsarchiv, Allgemeines Verwaltungsarchiv (dále OeStA/AVA), Familienarchiv (dále FA) Harrach, sign. HS 633 (inventář městského paláce ve Vídni, s. d., nefoliované strany). 
a druhém patře. $V$ první $z$ kuchyní stály čtyři skř́ně ze dřeva, do nichž se ukládalo nádobí. K odkládání předmětu sloužil stojan a $\mathrm{k}$ sezení tu sloužilo několik sedátek. Na velkém stole ze dřeva s plotýnkou a železným mlýnkem se připravovala káva. Ta se sladila, o čemž svědčí zapsané kleště na cukr. Ve druhém patře paláce byla kuchyně značně rozsáhlejší. Její centrum představoval velký stůl z měkkého dřeva se dvěma krájecími deskami. K vaření čaje sloužily trri kotle, do nichž se přesypával z mosazné dózy. Uvařený čaj se naléval do konvic a následně i do připravených šálků. Na přípravu kávy se použivalo deset přístrojů, šest jich bylo z bílého a tři pražící príistroje $z$ černého „plechu“ ${ }^{28}$ Kuchaři mohli využít k vaření i rendlíky. Kávová zrna se zprvu rozemlela v mlýnku a následně se uchovávala ve třech velkých „plechových“ dózách opatřených poklopem. Černý nápoj se po uvaření naléval až do dvaceti dvou konviček. K následnému podávání sloužilo dvanáct šálků se čtyřmi podtácky a dvanácti lžičkami. K oslazení nápojů se využíval cukr uložený v cukřenkách a skleněné dóze na slazení. Cukr se ale předtím musel odsekat $\mathrm{z}$ homolí a následně prosít, $\mathrm{k}$ čemuž se využívalo dřevěného síta. ${ }^{29}$ Po prosetí se sypký materiál uchovával ve zlatém bíle květovaném hrnci. Do nápojů se přidávalo mléko, proto se $\mathrm{v}$ harrachovské kuchyni nacházely rendlíky a hrnce na jeho ohřívání. Nápoje se zjemňovaly i smetanou, $\mathrm{k}$ čemuž kuchaři využívali konvičky a lžičky. K následnému servírování byl $\mathrm{v}$ harrachovské kuchyni uložen bílý pozlacený porcelán. Servis se skládal z konviček na kávu, pohárů na čokoládu, lžiček na smetanu a cukřenek. ${ }^{30}$

Vybavení kuchyně na prŕpravu čokolády vypadalo obdobně. Na ditrichštejnském zámku v Napajedlech se v sedmdesátých letech 18. století nacházela kuchyně specializovaná právě na čokoládu. Vybavená byla měděnými rendlíky, které se daly uložit do dřevěných skříní, pracovalo se tu na deseti dřevěných stolech a celou místnost osvětlovalo několik světel. $\mathrm{Na}$ zámku se nacházely zásoby pochutin navážené na kilogramy, z kterých kuchaři prípravovali (káva, čaj a čokoláda) a dochucovali (vanilka, cukr) nápoje. ${ }^{31}$ Cukrárny zřizované v sídlech dodávaly na šlechtický stůl nejen cukrovinky, ale také exotické nápoje. V cukrárně na zámku Duchcov měli Valdštejnové $\mathrm{k}$ dispozici šálky, poháry a konvice na kávu a čokoládu a železný mlýnek na mletí kávy. ${ }^{32} \mathrm{~V}$ dolnorakouské rezidenci Rohrau rodu Harrachů se nacházela

28 Plech nebyl ve zkoumaných inventárích bližze určen, proto je v článku v uvozovkách.

29 V inventáŕích nebyl uveden záznam o cukrových homolích. Více k tomu srov. Bohumír SMUTNÝ, Po stopách kostky cukru v Dačicích. O jednom svètovém prvenství, Dačice 1995.

30 Srov. E. Lukášová - V. OTAvsкÁ, Aristokratický interiér, s. 44-45. Autorky edičně zpř́stupnily vybavení kuchyně na zámku $\mathrm{v}$ Litomyšli v roce 1711 . $\mathrm{V}$ inventáŕi jsou uvedeny i předměty $\mathrm{k}$ př́pravě kávy a čokolády.

31 MZA Brno, C2 Tribunál - pozůstalosti, sign. D 101, kart. 30 (inventáŕ zámku Napajedla 1772, nefoliované strany).

32 SOA Praha, RA Valdštejnů, inv. č. 3133, kart. 16 (inventáŕ zámku Duchcov 1775, nefoliované strany). 
v 18. století místnost označovaná jako kavárna (Kaffeezimmer). Místnost určená $\mathrm{k}$ společenskému posezení a konverzaci. ${ }^{33}$ V ní se káva po rozemletí mlýnkem připravovala ve dvou hrncích nebo v rendlíku, přelila se do černé konvičky a servírovala se společně s konévkou na mléko. Zrna se ukládala do třech košů a poté se užil př́stroj z mosazi na jejich rozemletí. ${ }^{34}$

Po procesu př́pravy následovalo na šlechtických sídlech servírování nápojů. K tomu sloužily konvice, které byly povětšinou opatřeny víkem, aby $\mathrm{z}$ nich neunikalo teplo, alespoň tedy do té doby než se dostaly na šlechtický stůl. Ke snadnější manipulaci s konvicí sloužila rukojet'. Nápoj se připravoval i do džbánku s poklopem. Káva a čaj se rozlévaly do šálků, k nimž patřily podšálky. Čokoláda se pila z pohárků, které stály na podtáckách. Čaj se louhoval v sítkách či cednících. K míchání nápojů se používaly lžičky. Součástí servisů na popíjení exotických nápojů byla i konvička na smetanu či na mléko pro zjemnění nápoje a cukřenka. ${ }^{35} \mathrm{Cukr}$ se postupně stal pro svou sladkou chut' neodmyslitelnou součástí podávání exotických nápojů. Bez cukru byly káva, čaj i čokoláda značně hořké a tím pádem pro šlechtickou společnost zprvu neoblíbené. ${ }^{36}$ Chut' nápojů se obohacovala o vanilku, chilli, skořici, hřebíček, kardamon, anýz, jasmín a další koření. ${ }^{37}$ Celé soubory nádobí se servírovaly na specializované stolky - kávové a čajové. ${ }^{38} \mathrm{~K}$ pití nápojů se podávaly i cukrovinky a dezerty. Oblíbenými se staly koláče, studené nákypy, želé, pudinky a ovocné kompoty. ${ }^{39}$ Při konzumaci exotických nápojů se občasně kouřil či šňupal tabák. Inventáře vypovídají o této zálibě urozenců prostř̌ednictvím výčtu počtu dýmek na tabák, tabatěrek i samotného tabáku. ${ }^{40}$ Setkávání šlechticů s hosty u šálku kávy, čaje či čokolády se doplňovalo

33 E. LukÁšová - V. OTavs ká, Aristokratický interiér, s. 18.

34 OeStA/AVA, FA Harrach, Wirtschaftsbücher Böhmen, sign. Ö 906 (inventáŕ zámku Rohrau 1796, nefoliované strany).

35 Srov. Jiř́ ChLÁdek - Ilona Nová, Porcelán kolem nás, Praha 1991, s. 80-81; V. ŠTajnochr, Zámecké kuchynĕ, s. 208.

A. Menninger, Genuss, s. 320.

37 ТАмте́ž, s. 58, 355, 360.

38 Srov. Filip Suchomel - Zlata Černá, Pưvaby orientálního salonu, Brno 2007, s. 18. Autoři píší o stolečku na pěti nožkách dovezeného z Japonska, původem z první poloviny 18. století.

39 Josef HRdičKa, Hodovni stül a dvorská společnost. Strava na raně novověkých aristokratických dvorech v českých zemích (1550-1650), České Budějovice 2000 (= Monographia historica 1), s. 204.

40 Např. SOA Plzeň, pracoviště Klášter u Nepomuku, RA Nosticů, inv. č. 932, kart. 145 (inventář zámku Sokolov 1681, nefoliované strany); SOA Třeboň, pracoviště Jindřichův Hradec, RA Černínů, nečíslovaný fascikl k 30. dubnu 2018 (inventář pražského paláce 1733). K tabáku zejména A. MENNInger, Tabak, Kaffee, Tee und Schokolade in Wissenskulturen der Frühen Neuzeit, in: Annerose Menninger - Katharina Niemeyer (edd.), Drogen: Aspekte einerglobalen Konsumgeschichte, Köln 2009. Dostupné na http://www.zeitenblicke.de/2009/3/menninger/ (Odkaz ověřen k 19. 5. 2018). 
o hraní her. ${ }^{41}$ Šlechta se pravidelně denně či jednou za týden scházela u tzv. Caffé Cräntzgen. Při takových schůzkách se popíjela káva a hrála se karetní hra L'Hombre. $^{42}$ Vytvořil se tak prostor, který sloužil jako místo konverzace a výměny zpráv. Popíjení kávy, čaje a čokolády postupem času nabylo ustálené podoby. Počátkem 18. století vznikaly př́ručky, které se týkaly chování v dámských pokojích, některé jejich části se věnovaly kávě a dalším nápojům, které se zde pily. ${ }^{43}$

Nádoby sloužící ke konzumaci těchto nápojů se nejčastěji vyráběly z porcelánu. Za nejreprezentativnější byl považován čínský a japonský porcelán, ovšem ve zkoumané době již převažoval porcelán vyrobený na evropském kontinentu. ${ }^{44}$ Šlechtici, jak ukázal výzkum inventářù, pořizovali do svých domácností zejména porcelán vídeňský a míšeňský (drážd’anský). Porcelán pocházející z Asie se stal v 18. století součástí výstavních prostor galerií, jak tomu bylo i v př́padě rodu Černínů. ${ }^{45}$ Tak se jeho funkce praktická změnila na značně reprezentativní až uměleckou a dekorativní. Barevná škála porcelánu byla rozsáhlá - od modré, hnědé po červenou, černou a v neposlední řadě i zelenou. Na zámeckých sídlech se vyskytoval porcelán bílý i malovaný, Využívala se kombinace bílé a modré barvy, v menši míře se uplatnilo spojení bílé a červené, či bílé, červené a zelené. Porcelánové nádobí se obvykle zlatilo a stříbřilo. Předměty sloužící k popíjení kávy, čaje a čokolády se dekorovaly, užívaly se květy (červené, zelené, modré, zlaté, nebo kombinace modrých a červených květů). Zelené květy se zpravidla malovaly na předměty ke konzumaci čaje, červenými se zdobilo nádobí na popíjení kávy. ${ }^{46}$ Dekorace byly inspirovány motivy z flóry a fauny. Mimo květy se předměty zdobily

41 A. Kř́ǐžoví, Pánský salon na šlechtickém sídle. Ušlechtilé záliby a nerestné zábavy aristokratů, Brno 2010, s. 25-34.

42 K. Č́terný, Káva, s. 151; A. Menninger, Genuss, s. 350.

43 Např. Gottlieb Siegmund Corvinus, Nutzbares, galantes und curioses Frauenzimmer-Lexikon, Leipzig 1715 , s. 162-163.

44 Dagmar Hejdová - Emanuel Poche, Porcelán, Praha 1994, s. 14-15. Dále k porcelánu např. Alena Braunová, Kouzlo keramiky a porcelánu, Praha 1978; Jan Diviš, Evropský porcelán, Praha 1985; J. Chládex, Porcelán, Praha 2000; týž, Klasika porcelánu, Praha 2007; Richard Šubrt, Mišeňský porcelán 1710-2000. Böttger, Höroldt, Kändler, vybrani modelárí, značky, Praha 2009.

45 SOA Třeboň, pracoviště Jindřichův Hradec, RA Černínů, nečíslovaný fascikl k 30. dubnu 2018 (inventář pražského paláce 1733).

46 F. Polleross, ,Spanische Chocolate" und,,indianische Cabinete"-Köstlichkeiten aus der Neuen Welt und exotisches Ambiente, in: F. Polleross - A. Sommer-Mathis - Ch. F. Laferl (edd.), Federschmuck, s. 105-124, zde s. 121; F. Suchomel - Z. ČErnÁ, Pưvaby, s. 44. Zelené květy na předmětech k popíjení čaje jsou zapsány v inventáŕích, a to např. SOA Třeboň, pracoviště Český Krumlov, Schwarzenberská inventární kontrola České Budějovice, inv. č. 206, kniha 206 (inventář cukrárny v městském paláci ve Vídni 1722, nefoliované strany). Červené květy např. TAmTÉž, RA Buquoyů, sign. 206.349, kniha 400 (inventář zařízení a nářadí ve správě cukráře 1770, nefoliované strany). 
i rozličnými zviŕaty a ptáky. ${ }^{47}$ Své zastoupení měla též figurální dekorace, která ani jednou nebyla v inventářích bliže specifikovaná (např. čínská porcelánová figurální skř́iń na kávu). ${ }^{48}$ Často bývali na čajových konvicích zobrazováni Číňané a na kávových Indiáni. ${ }^{49} \mathrm{Za}$ vrchol ve zdobení lze považovat předměty, jejichž dekorace sloužily $\mathrm{k}$ reprezentaci rodu. Tak si František Leopold Buquoy (1703-1767) nechal jeden $\mathrm{z}$ pohárů na čokoládu dekorovat svým hraběcím jménem. ${ }^{50}$ K reprezentaci využívali předměty i Schwarzenberkové, kteří si na nádobí nechali malovat rodový erb. ${ }^{51}$ Množství porcelánového nádobí se v každém sídle lišilo, někteří šlechtici vlastnili podle inventářů jen pár kusů, jiní až několik desítek předmětů. Kupř́ikladu na stříleckém zámku Petřvaldských se podle inventáře $\mathrm{z}$ roku 1762 nacházelo jedenáct párů hrníčků na čaj. Na druhou stranu
Schwarzenberkové ve vídeňském městském paláci užívali sto třináct tácků pod poháry k pití kávy a čokolády. ${ }^{52}$ Porcelán ve zkoumané době platil za velice nákladnou a luxusní, pro každého nedostupnou a tím pádem i zcela výjimečnou záležitost. Majitel jeho vlastnictvím ukazoval svou distinktivní nadřazenost.

Ve šlechtických domácnostech se nacházely i předměty vyrobené $\mathrm{z}$ majoliky a z terry sigillaty. Majolika v období 18. století oproti porcelánu ztrácela na atraktivnosti, a proto je tento materiál v inventáŕích zastoupen jen několika kusy. Výrobky se okázale nezdobily. ${ }^{53}$ Nejmenší zastoupení $\mathrm{v}$ inventářích $\mathrm{z}$ keramických hmot měla terra sigillata. Kromě toho, že tento materiál působil reprezentativně, se mu prripisovaly i léčivé a ochranné účinky. Předměty $z$ této červenohnědé keramiky se ukládaly do šlechtických kunstkomor. ${ }^{54}$ Nádobí z terry sigillaty vlastnili

47 Např. TAmтÉž, pracoviště Jindřichův Hradec, RA Černínů, nečíslovaný fascikl k 30. dubnu 2018 (inventář pražského paláce 1733).

48 TAмтÉž, RA Buquoyi̊, sign. 206.340, kniha 391 (inventář hraběcí domácnosti 1772, nefoliované strany). Alena Křížová v katalogu k výstavě uvádí několik př́kladů figurek s tematikou kávy a čokolády. Srov. A. Křížová, Káva, čaj a čokoláda, s. 6, 9, 19.

49 F. Polleross, ,Spanische Chocolate“, s. 121.

50 SOA Třeboň, RA Buquoyů, sign. 206.341, kniha 392 (inventář hraběcí domácnosti 1774-1775, nefoliované strany).

51 Tамте́ž, pracoviště Český Krumlov, Schwarzenberská inventární kontrola České Budějovice, inv. č. 206, kniha 206 (inventář cukrárny v městském paláci ve Vídni 1722, nefoliované strany).

52 TАмте́ž, inv. č. 207, kniha 207 (inventář cukrářského zařízení v městském paláci ve Vídni 1727, nefoliované strany).

53 Zdeněk KnÁpex, Rukovèt sbèratele porcelánu, Olomouc 2003, s. 330. Př́klady výskytu majoliky v inventářích SOA Plzeň, pracoviště Klášter u Nepomuku, RA Nosticů, inv. č. 1114, kart. 160 (inventář pražského paláce 1736, nefoliované strany); SOA Praha, RA Valdštejnů, inv. č. 3441, kart. 45 (inventář zámku Duchcov 1731, nefoliované strany).

54 Beket Bunovinská, Terra sigillata v rudolfinské kunstkomoře, in: Dalibor Prix (ed.), Pro arte. Sborník k poctě Ivo Hlobila, Praha 2002, s. 289-293, zde s. 289. 
Černínové, Nosticové a Schwarzenberkové a popíjeli z něho čaj. ${ }^{55}$

Kromě keramiky měly své zastoupení i nádoby $z$ kovů, tedy $z$ cínu, mědi, mosazi, ,plechu“ a železa. Cín představoval materiál náročný na údržbu a ve zkoumané době ustupoval do pozadí před vzácnějším porcelánem. ${ }^{56}$ Naproti tomu měd' se stala velice oblíbenou. ${ }^{57}$ Vyráběly se z ní konvičky na exotické nápoje, lžičky, ale i kotlíky na čaj či čajovary. Uplatnění ve šlechtických domácnostech našly i předměty z mosazi a blíže neurčeného ,plechu“. U mosazi šlo o konvice, v případě ,,plechu“ o plechovky na čaj a kávu a o tácky. ${ }^{58}$ Železo se užívalo k výrobě mlýnků na kávu a rendlíků. ${ }^{59}$ Kovové nádobí se obvykle používalo $\mathrm{k}$ přípravě nápojů, a proto se nacházelo v kuchyních či cukrárnách. Za nejreprezentativnější se považovalo nádobí ze stříbra, které se častokrát pozlacovalo.

Šlechtici si do svých domácností pořizovali i umělecké kusy, které se vyráběly $\mathrm{z}$ jaspisu, či se vyzdobovaly mušlovinou. ${ }^{60}$ Předměty sloužící ke konzumaci kávy, čaje a čokolády se v některých případech staly doslova uměleckými díly. Jejich reprezentativní složka převážila tu praktickou a tyto nádoby, jako např. poháry z kokosových ořechů či exotického dřeva, představovaly hmotný symbol šlechtické

55 SOA Třeboň, pracoviště Český Krumlov, Schwarzenberská inventární kontrola České Budějovice, inv. č. 206, kniha 206 (inventáŕ cukrárny v městském paláci ve Vídni 1722, nefoliované strany); TAMTÉž, pracoviště Jindřichův Hradec, RA Černínů, nečíslovaný fascikl k 30. dubnu 2018 (inventář pražského paláce 1733); SOA Plzeň, pracoviště Klášter u Nepomuku, RA Nosticủ, inv. č. 1114, kart. 160 (inventár pražského paláce 1736, nefoliované strany).

56 Slavomír RavıK, Svèt starožitností, Praha 1972, s. 177-179, 221-222.

57 V. ŠTAjNochr, Zámecké kuchyně, s. 169, 208-209;SOA Třeboň, RA Buquoyů, sign. 206.348, kniha 399 (inventář zařízení a nářadí ve správě cukráře 1769, nefoliované strany); тАмтÉž, sign. 206.340, kniha 391 (inventář hraběcí domácnosti 1772, nefoliované strany); тAмтÉž, sign. 206.329, kniha 380 (inventár buquoyské rezidence v Nových Hradech 1784, nefoliované strany); MZA Brno, C2 Tribunál - pozůstalosti, sign. B 43, kart. 11 (inventáŕ Police 1720, nefoliované strany); тAMTÉž, sign. C 55, kart. 25 (inventář zámku Uherčice 1770, nefoliované strany) a další.

58 Mosazné předměty se nacházely v inventáŕích MZA Brno, RA Questenberků, inv. č. 6126, kart. 737 (inventář zámku Jaroměřic nad Rokytnou 1752), za poskytnutí přepisu inventáře děkuji PhDr. Rostislavu Smíškovi, Ph.D. Dále MZA Brno, C2 Tribunál - pozůstalosti, sign. P 103-2, kart. 168 (inventáŕ zámku Stř́lky 1762, nefoliované strany) a plechové SOA Třeboň, RA Buquoyů, sign. 206.340, kniha 391 (inventář hraběcí domácnosti 1772, nefoliované strany); MZA Brno, C2 Tribunál - pozůstalosti, sign. B 43, kart. 11 (inventáŕ Police 1720, nefoliované strany); тAмтÉž, sign. C 55, kart. 25 (inventár zámku Uherčice 1770, nefoliované strany).

59 SOA Třeboň, RA Buquoyů, sign. 206.350, kniha 401 (inventář stříbra a náčiní ve správě stolníka 1769, nefoliované strany); MZA Brno, RA Questenberkủ, inv. č. 6126, kart. 737 (inventář zámku Jaroměřic nad Rokytnou 1752), za poskytnutí přepisu inventáře děkuji PhDr. Rostislavu Smiškovi, Ph.D.

60 SOA Třeboň, Schwarzenberská inventární kontrola České Budějovice, inv. č. 138, kniha 138 (inventár městského paláce ve Vídni 1724, nefoliované strany); тAмTÉž, RA Buquoyů, sign. 206.350, kniha 401 (inventář stř̌bra a náčiní ve správě stolníka 1769, nefoliované strany); тAMTÉž, sign. 206.349, kniha 400 (inventář zařízení a nářadí ve správě cukráře 1770, nefoliované strany). 
reprezentace. ${ }^{61}$ Např́klad Valdštejnové si z ,indiánského“ dřeva nechali vyrobit př́stroj na čaj, který jim sloužil na zámku v Duchcově. ${ }^{62} \mathrm{Na}$ druhou stranu se v přípravných místnostech užívalo i obyčejné dřevěné nádobí. To sice nebylo reprezentativní, ale za to dostupné. Ve šlechtických domácnostech se $\mathrm{z}$ tohoto materiálu vyskytovaly konvice, poháry i mlýnky. ${ }^{63}$

Káva, čaj i čokoláda jsou již zcela běžnou součástí naší každodennosti. Od jejich prvopočátků u české a moravské šlechty uplynulo bezmála čtyři sta let. Zkoumané inventáře ukazují na využívání konkrétních předmětů v místnostech zámku či paláce již v 17. století. Kupř́ikladu před rokem 1681 se čokoláda vařila na sokolovském zámku, kde nádobí $\mathrm{k}$ její přípravě měla ve své domácnosti hraběnka Eleonora Marie Nosticová (1619-1681). ${ }^{64}$ Interiéry sídel a jejich vybavení této doby jsou prozatím málo prozkoumané, což badatelům nabízí velké možnosti $\mathrm{k}$ výzkumu, a to i na poli mimoevropských vlivů, které šlechta přijímala na svá zámecká a palácová sídla. O oblibě nápojů ve zkoumaném období nesvědčí pouze množství předmětů sloužících k jejich konzumaci, ale také umělecké provedení, estetické hledisko či zdokonalování praktické stránky př́ipravy a podávání. Exotické pochutiny patřící výhradně do šlechtických domácností se v 19. století dostaly i do měštanských rodin a na venkov. O tomto propadu a postupném zevšednění svědčí kupř́íkladu vzpomínka Marie Strettiové (1876-1953) na každoroční vánoční nadílku konanou v plaském zámku u Metternichů od sedmdesátých let 19. století: ,Jednou dèti zasedly ke stolu; sluha s konvicemi došel k malé, asi čtyřleté Olze s otázkou: Čaj nebo kávu? Jo, čokoládu, znèla určitá a klidná odpovéd'. Kněžna se dala do smíchu a nařídila vyhovèti dèvčátkovu próníi." ${ }^{65}$

Káva, čaj a čokoláda nebyly jediné pochutiny, které se konzumovaly a využívaly

${ }^{61}$ Např. Josef Petráň psal o stř́ibrném poháru z počátku 17. století s víkem, jehož kupu tvořila skořápka kokosového ořechu. Oblíbený byl exotický materiál jako skořápky pštrosích vajec, mořských korálů, slonoviny, lastur apod., ten se zasazoval do stř́ibra, které se často i zlatilo. J. Petráň, Dějiny hmotné kultury II/1, s. 99. Poháry z kokosového ořechu se dochovaly dodnes, např. na Státním zámku Rájec nad Svitavou se nachází pohár ze 17. století. Státní zámek Rájec nad Svitavou, inv. č. RA02830a-b. Pohár je vystaven na zámku v místnosti nazývané Klenotnice. Více k tomu Michal KonečnÝ, Zámek Rájec nad Svitavou, Kroměříž 2013, s. 145.

62 SOA Praha, RA Valdštejnů, inv. č. 3133, kart. 16 (inventář zámku Duchcov 1775, nefoliované strany).

63 SOA Třeboň, RA Buquoyů, sign. 206. 339, kniha 390 (inventář hraběcí domácnosti 1767-1768, nefoliované strany); TAMTÉž, pracoviště Český Krumlov, Schwarzenberská inventární kontrola České Budějovice, inv. č. 214, kniha 214 (inventář cukrárny v městském paláci ve Vídni 1753, nefoliované strany) apod.

64 SOA Plzeň, pracovišš̌ Klášter u Nepomuku, RA Nosticů, inv. č. 932, kart. 145 (inventář zámku Sokolov 1681, nefoliované strany).

65 Marie Strettioví, O starých časech a dobrých lidech, Praha 1947, s. 153. 
na šlechtických sídlech. Šlechta postupně přijímala i další mimoevropské produkty, kterým nebyla věnovaná náležitá badatelská pozornost. Mezi ně se řadí exotické květiny, koření, ovoce a zelenina, ale i hmotné předměty jako koberce či zbraně pocházející z americké, asijské nebo orientální provenience. ${ }^{66}$ Jejich výzkum by mohl do budoucna podat zevrubnější náhled na myšlení šlechtické společnosti. Následující badatelé se mohou zaměřit na širší spektrum urozených příslušníků a jejich sídla. Možností, která se v tomto př́padě přímo nabízí, je zkoumat a srovnávat inventáře šlechtické s měštanskými. Řešena by mohla být otázka průniku předmětů ze šlechtického do měštanského prostředí, ovlivňování, množství či symbolika předmětů. Možnost výzkumu se dá rozšírít o další prameny, zvláště prameny osobní povahy, účty apod. Nastíněná cesta $\mathrm{v}$ bádání vede $\mathrm{k}$ poznání globalizačních a modernizačních procesů prostř́ednictvím mimoevropských vlivů, které měly dopad na raně novověkou šlechtickou společnost. ${ }^{67}$

66 Bádání o exotických produktech, pochutinách a předmětech je teprve v počátcích, čeští historici se prozatím zabývali pouze jednotlivými exotiky. Např. Marie Ryantová, Tulipán - módní kvétina 17. stoleti, Dějiny a současnost 19,1997, č. 4, s. 36-38; Vítězslav PRCHAL, Obraz krestanského rytíre? Turcika ve šlechtických zbrojnicích raného novověku, Theatrum historiae 2, 2007, s. 123-136; Miroslav Cvrk, Ananasy ze Židlochovic, Jižní Morava 47, 2011, s. 307-312. O exotikách se lze dočíst i v odborných knihách, např. Tomáš RATAJ, České zemè ve stínu pülměsice. Obraz Turka v raně novověké literatuře z českých zemí, Praha 2002; Svatava Raková, Dobrodruzi, puritáni a Indiáni. Angličané v Novém svétě, Praha 1998; TÁž, Víra, rasa a etnicita v koloniálni Americe, Praha 2005; Markéta Křížová, Mayové. Vic než záhady dávné civilizace, Praha 2001; Táž, Aztékové. Pưvab a krutost indiánské civilizace, Praha 2005; тÁž, Inkové. Nejmocnější indiánskýstát, Praha 2006; Vítězslav Prchal, Válka, zbraně a zbroj v reprezentačnich strategiich české a moravské aristokracie v letech 1550-1700, Praha 2012 a další.

67 Zatím za nejlépe pojatý pohled na pochutiny, proces jejich přijímání a modernizační a globalizační otázky s tím spojené zpracovala Annerose Menninger ve své knize, která byla v tomto článku několikrát citovaná. Srov. A. Menninger, Genuss. Za velice zdařilou a prospěšnou v tomto směru bádání lze považovat disertační práci Benity Wister, jež věnovala pozornost kakau. Benita Wister, Kakao: Vom habsburgischen Hofgetränk zur niederländichen Kolonialware. Der Diffusionsprozesses der Schokolade in Mitteleuropa vom 17. bis 19. Jahrhundert vor dem Hintergrund eines konsumspezifischen Kulturtransfers am Beispiel der Steiermark und Westfalens, Graz 2002 (Disertační práce). Bohužel $\mathrm{v}$ české historiografii žádná podobná práce zatím nevznikla. 
Dana Marešová

\section{The Finest Beverages}

Coffee, Tea and Chocolate in the Aristocratic Residences of Bohemia and Moravia in the Second Half of the $17^{\text {th }}$ and $18^{\text {th }}$ Century (Abstract)

The interiors of residences and their furnishing with objects from the $17^{\text {th }}$ and $18^{\text {th }}$ century that originated outside Europe belong to a little investigated field of interest. Thus, they offer the researchers a vast range of opportunities. The castle and palace inventories represent one of the possible archival sources on which base the exotic objects can be examined. These sources may allow the researchers some closer insights into the mind and world of thoughts of the residence owners and to answer questions connected with the exotic objects they had purchased for their castles.

The basis for this paper is an in-depth investigation of eighty inventories on exotic food and delicatessen. The author of the paper will describe the rooms in the castles and residences where these beverages had been prepared and consumed, the process of serving, different kinds of beverages and material structure. Furthermore, she will focus on topics such as the matter of representation, the aristocrat's taste in art and world of ideas.

KEY WORDS

Coffee; Tea; Chocolate; Aristocratic Residences of Bohemia and Moravia; $17^{\text {th }}$ and $18^{\text {th }}$ Century 